\title{
PENGARUH KONSENTRASI GULA DAN RAGI DALAM PEMBUATAN CUKA DARI ROSELLA (Hibiscus sabdariffa.L) TERHADAP MUTU CUKA ROSELLA
}

\section{The Effect of Sugar and Yeast Concentration in Vinegar Making from Rosella (Hibiscus sabdariffa.L) on The Quality of Rosella Vinegar}

\section{Firdausni}

Balai Riset dan Standardisasi Industri Padang

JI. Raya LIK No. 23 Ulu Gadut Padang 25164

e-mail: firdausni85@gmail.com

Diterima: 19 Agustus 2013, revisi akhir: 16 Oktober 2013 dan disetujui untuk diterbitkan: 24 Oktober 2013

\begin{abstract}
ABSTRAK
Rosella (Hibiscus sabdariffa.L) telah digunakan secara tradisional sebagai minuman yang berkhasiat fungsional. Bunga rosella mengandung flavonoid metabolit sekunder, terpenoid, dan vitamin $\mathrm{C}$ yang berfungsi sebagai antioksidan. Penelitian ini bertujuan untuk melihat pengaruh pemakaian gula dan ragi terhadap mutu cuka. Penelitian dilakukan dengan perlakuan penggunaan gula pasir $(10,15,20,25) \%$, fermentasi dengan ragi Saccharomyces cerevisiae $(2,4,6) \mathrm{g}$ dan waktu fermentasi sampai tiga minggu. Hasil fermentasi berupa cuka rosella selanjutnya diuji $\mathrm{pH}$, kandungan asam asetat, kadar sari dan uji aktifitas antioksidan yang terdiri dari uji kualitatif fenolik, flavonoid, dan \% inhibisi. Hasil penelitian optimal diperoleh pada perlakuan penggunaan gula $20 \%$ dan penambahan ragi $6 \mathrm{~g}$ dengan hasil analisis $\mathrm{pH} 2,67$, asam asetat $14,80 \%$, kadar sari $7,15 \%$ dan $\%$ inhibisi $31 \%$ serta secara kualitatif mengandung senyawaan fenolik dan flavonoid.
\end{abstract}

\section{Kata Kunci : Rosella, cuka rosella, asam asetat}

\begin{abstract}
Rosella (Hibiscus sabdariffa.L) has been traditionally used as nutritious functional beverages. Rosella flowers contain flavonoid secondary metabolites, terpenoids, and vitamin $C$, which are considered as antioxidant. Research aims to see the effect of sugar and yeast on quality of vinegar. The study was conducted with the treatment of sugar utilization $(10,15,20,25) \%$, fermentation with yeast Saccharomyces cerevisiae $(2,4,6) \mathrm{g}$ and fermentation time until three weeks. Rosella vinegar as a results of fermentation further was analyzed the $\mathrm{pH}$, acetic acid content, extract content and antioxidant activity test consisted of qualitative test of phenolic, flavonoid, and \% inhibition. Result of the optimal research was obtained in the treatment of sugar utilization $20 \%$ and the addition of yeast $6 \mathrm{~g}$ with analysis result of $\mathrm{pH} 2.67$, acetic acid $14.80 \%$, extract content $7.15 \%$, and \% inhibition 31\%, moreover it contained phenolic and flavonoids compounds qalitatively.
\end{abstract}

Keywords: Rosella, Rosella vinegar, acetic acid

\section{PENDAHULUAN}

Tanaman rosella (Hibiscus Sabdariffa.L) merupakan tumbuhan berpembuluh yang menghasilkan biji, berbunga termasuk kelas Dikotil dari sub kelas Dillenidae, ordo Malvales, famili Malvaceae dari genus Hibiscus merupakan tanaman perdu. Saat muda batang dan daunnya bewarna hijau, namun ketika beranjak dewasa dan berbunga batangnya akan berubah jadi coklat kemerahan, berbentuk silindris dan berkayu, memiliki banyak cabang.

Kandungan yang terdapat dalam kelopak bunga rosella dalam $100 \mathrm{~g}$ bahan diantaranya kadar air $9,2 \mathrm{~g}$; protein $1,15 \mathrm{~g}$; lemak $2,26 \mathrm{~g}$; serat $12,00 \mathrm{~g}$; abu $6,90 \mathrm{~g}$; Kalsium 1,27 mg ; Fosfor 273,20 mg ; zat besi $8,98 \mathrm{mg}$ : karoten $0,03 \mathrm{mg}$; thiamin 0,12 
; Riboflavin 0,28 mg; Niacin 3,77 mg dan asam askorbat $6,70 \mathrm{mg}$. Selanjutnya menurut Maria (2009) bahwa kandungan vitamin dalam rosella cukup lengkap, yaitu vitamin C, A, D, B1, B2 dan asam amino. Asam amino yang diperlukan tubuh, 18 diantaranya terdapat dalam kelopak bunga rosella, termasuk arginin Kandungan vitamin C bunga rosella 3 kali lebih banyak dari anggur hitam, 9 kali dari jeruk citrus, 10 kali dari buah belimbing dan 2,5 kali dari jambu biji.

Warna bunganya yang menarik sehingga banyak ditanam di pekarangan rumah sebagai tanaman hiasan. Pada berbagai daerah ukuran rosella selalu berbeda, begitu juga dengan warna mahkotanya ada yang merah muda, merah kehitaman dan merah kecoklatan.

Sebagai tanaman hiasan, para petani atau penanam bunga rosella pernah memanfaatkan sebagai pembuat tekstil, daun mudanya untuk dikonsumsi dan bunganya dijadikan sirup dan sekarang telah ada yang mengeringkan bunga rosella tersebut untuk dijual didepot obat sebagai teh rosella. Bagian yang terpenting dari bunga rosella adalah kelopak bunganya, yang sebenarnya adalah kelopak buah, namun karena bentuknya seperti bunga maka orang menyebutnya bunga rosella (Allison,2013).

Bahan aktif dari kelopak bunga rosella menurut Wirjatmadi (2008) adalah grossypeptin, antosianin, glucide hibiscin dan flavonoid. Selain itu kelopak bunga rosella juga mengandung vitamin C (260280 mg setiap 100 gram), vitamin D, vitamin B1, vitamin B2, niacin, riboflavin, betakaroten, zat besi, asam amino, polisakarida, omega3, kalsium dal lain-lain. Banyaknya kandungan zat-zat bermanfaat yang ada dalam kelopak bunga rosella tersebut seperti adanya gossy peptin, anthocyanin dan glukoside hibiscin yang mempunyai efek diuretic dan choleretic, memperlancar peredaran darah, mencegah tekanan darah tinggi, meningkatkan kinerja usus serta berfungsi sebagai tonik (Seema Patel, 2013).

Pengolahan bunga rosella menjadi cuka belum banyak diketahui. Pembuatan cuka rosella melalui proses fermentasi. Fermentasi akan banyak memberikan keuntungan yang diperoleh akibat terurainya senyawa komplek menjadi lebih sederhana dan perubahan sifat organoleptik. Pengolahan buinga rosella menjadi produk yang banyak ditemui seperti jeli, saus, teh, sirup, dan manisan rosella. Namun pengolahan rosella menjadi cuka mungkin belum banyak kita diketahui. Teknologi fermentasi pengolahan bunga rosella menjadi cuka merupakan inovasi yang baru. Keuntungan dari produk makanan yang difermentasi baik dari sifat-sifat organoleptik (indrawi), peningkatan nilai gizi ataupun sanitasi memberikan penampakan, dan cita rasa yang khas, misalnya pada tempe, oncom, tauco, berbeda dari penampakan atau rasanya dengan bahan aslinya kedelai. Fermentasi juga turut mempertinggi nilaii gizi, karena mikroba bersifat memecah senyawa kompleks menjadi senyawa sederhana. Pada fermentasi apel menjadi cuka apel juga ditemukan fakta adanya peningkatan konsentrat polifenol seperti katekin, quercetin dan tannin yang lebih tinggi dibanding pada buah aslinya. Ketiga jenis polifenol ini berfungsi untuk menekan dan menghambat radikal bebas penyebab kanker dan penyakit degeneratif, seperti jantung koroner, diabetes, rematik dan stroke (Zoriah Aziz et al, 2013).

Dari penelitian terbukti bahwa kelopak bunga rosella mempunyai efek anti hipertensi, kram otot dan mempunyai efek antibakteri, mengurangi efek alkohol dalam tubuh, mencegah pembentukan batu ginjal, memperlambat pertumbuhan jamur/bakteri/parasit penyebab demam tinggi, membantu melancarkan peredaran darah dengan mengurangi derajat kekentalan darah, ini terjadi karena asam organik, polisakarida dan flavonoid yang terkandung dalam ekstrak kelopak bunga rosella (Maria, 2009). Menurut Nurfaridah, (2005) manfaat fungsional dari bunga rosella karena mengandung kadar zat anti oksidan jauh lebih tinggi dibandingkan dengan kumis kucing dan bunga knop yang dapat menghambat radikal bebas yang menjadi penyebab penyakit kronis seperti kerusakan ginjal, diabetes me-llitus, jantung koroner hingga kanker. Selain itu radikal bebas juga dapat menyebabkan proses penuaan dini. Tubuh memerlukan suplemen zat antioksidan yang banyak terdapat dalam kelopak bunga rosella tersebut. Flavonoid dalam kelopak bunga rosella bermanfaat 
untuk mencegah kanker, terutama karena radikal bebas seperti kanker lambung dan leukimia. Rosella juga baik bagi penderita hipertensi, penyakit hati, osteoporosis serta melancarkan air seni (sebagai diuretik), melancarkan aliran darah (dapat mengurangi kekentalan darah), mencegah infeksi (sebagai anti bakteri, antiseptik, dan anti radang), mengobati sariawan karena kandungan vitamin $\mathrm{C}$, mengurangi kadar kolesterol darah dan lain-lain. Kandungan kalsium dalam kelopak bunga rosella cukup tinggi yaitu $486 \mathrm{mg} / 100 \mathrm{~g}$ yang dapat mengisi kepadatan tulang untuk mengurangi penyakit osteoporosis.

Bunga rosella telah lama dimanfaatkan untuk makanan fungsional karena dapat mencegah dan mengobati berbagai penyakit, kelopak bunga rosella dapat diambil sebagai bahan minuman segar, minuman teh, selai, jelly, manisan pewarna makanan. dan minuman lainnya (Maria, 2009).

Salah satu makanan fungsional dan secara teknologi tepat guna dan mudah diaplikasikan pada skala industri kecil rumah tangga adalah mengolah bunga rosella menjadi cuka rosella, yang dapat diolah dengan mencampur sari rosella tersebut dengan gula dan bahan tambahan lainnya.

Cuka bunga rosella bermanfaat untuk menurunkan tekanan darah dan membantu melancarkan peredaran darah dgn mengurangi derajat kekentalan darah dan meningkatkan imunitas tubuh.

Fermentasi bunga rosella menjadi cuka rosella membutuhkan sukrosa sebagai sumber energi, melalui pemakaian sukrosa (gula pasir) yang optimal akan dihasilkan cuka dengan rasa dan mutu yang baik.

Tujuan penelitian ini adalah untuk mengetahui jumlah penambahan gula dan penambahan ragi yang tepat terhadap karakteristik cuka rosella dengan menggunakan bunga rosella, sehinga diperoleh cuka rosella yang disukai dan bermanfaat kesehatan serta dapat meningkatkan penerimaan panelis terhadap cita rasa.

\section{METODOLOGI PENELITIAN}

Bahan utama yang digunakan dalam penelitian ini adalah bunga rosella yang didapat dari penjual di Siteba Padang.
Bahan pembantu terdiri dari gula pasir, urea, Sacharomyces cereviceae, $\mathrm{Na}_{2} \mathrm{HPO}_{4}$, bahan-bahan kimia untuk pengujian.

Peralatan yang digunakan antara lain, botol selai, pipa plastik, dan peralatan bantu lainnya serta peralatan laboratorium untuk pengamatan dan pengujian diantaranya pengaduk, tabung reaksi, pipet gondok $1 \mathrm{ml}$, labu erlenmeyer, , gelas ukur, thermometer, oven, kompor, kain kasa, timbangan analitik, labu Kjeldahl, corong, kertas saring, alat titrasi (buret), labu destilasi, blender, $\mathrm{pH}$ meter, botol, inkubator, cawan aluminium, desikator, soxlet, dan lain-lain.

Kegiatan penelitian dilakukan di laboratorium Baristand Industri Padang, sedangkan untuk pengujian fenolik, flavonoid dan persentase inhibisi dilakukan di laboratorium Fakultas Farmasi Universitas Andalas.

Rancangan yang digunakan dalam penelitian ini adalah Rancangan Acak Lengkap (RAL) dengan 2 (dua) faktor yaitu:

A. Jumlah Pemakaian gula
A1: Gula: $10 \%$
A2: Gula; $15 \%$
A3: Gula: $20 \%$
A4: Gula: $25 \%$, dan

B. Pemakaian ragi S. cereviseae

B1;Ragi $2 \mathrm{gr} / \mathrm{L}$

B2:Ragi $4 \mathrm{gr} / \mathrm{L}$

B3:Ragi $6 \mathrm{gr} / \mathrm{L}$

Penelitian pembuatan cuka rosella dilakukan dengan beberapa tahapan :

- Persiapan bahan

Bunga rosella yang diambil di daerah Siteba Padang dipisahkan dari bijinya. Selanjutnya $250 \mathrm{~g}$ rosella ditambahkan $1500 \mathrm{ml}$ air dihaluskan dan diambil ekstraknya.

- Fermentasi

Dilakukan penambahan nutrisi dengan gula pasir (10\%-25\%) dan penambahan $0,05 \% \quad \mathrm{Na}_{2} \mathrm{HPO}_{4}$, urea, dan $S$. Cereviceae sesuai perlakuan $(2,4,6) \mathrm{g}$. Selanjutnya dimasukkan ke wadah fermentasi dan didiamkan sampai 3 minggu

- Pembentukan Cuka Rosella

Hasil fermentasi dipanaskan dan disaring dan dilanjutkan dengan proses pembentukan cuka. 
Pengamatan fisik dan kimia dilakukan terhadap cuka rosella hasil fermentasi yaitu: $\mathrm{pH}$, kadar gula, kadar sari, kadar asam asetat. Kemudian untuk aktifitas antioksidan dengan analisis \% inhibisi, Uji fenolik dan uji flavonoid.

\section{HASIL DAN PEMBAHASAN}

\section{Pengaruh penambahan gula terhadap $\mathrm{pH}$ cuka rosella.}

Penambahan gula terhadap fermentasi rosella menjadi cuka rosella memberikan nilai pH cuka rosella yang dihasilkan berbeda. Adanya pengaruh penambahan gula terlihat dari hasil $\mathrm{pH}$ cuka yang berbeda dimana $\mathrm{pH}$ terendah pada penambahan gula $25 \%$. pH merupakan faktor yang mempengaruhi fermentasi. pH awal ekstrak bunga rosella 5,43 atau cenderung asam dan mengalami penurunan setelah melalui fermentasi. Rosella mengandung asam askorbat yang cukup tinggi. Wirjatmadi. (2008) menyatakan bahwa kandungan asam askorbat bunga rosella 260-280 $\mathrm{mg} / 100 \mathrm{~g}$ bahan.

Penambahan gula memberikan pengaruh terhadap $\mathrm{pH}$ cuka rosella yang dihasilkan (Gambar 1). $\mathrm{pH}$ terendah pada penambahan gula $25 \%$ dengan lama fermentasi 21 hari. Wignyonto (2001) menyatakan bahwa perubahan $\mathrm{pH}$ dalam fermentasi dikarenakan dalam aktivitasnya sel khamir akan menghasilkan etanol sebagai metabolit primer juga menghasilkan asam asam organik seperti asam asetat, asam malat, asam tartarat, asam sitrat dan asam lainnya.

Pengamatan $\mathrm{pH}$ terhadap cuka rosella (Apriyantono dkk, 2006) terlihat cenderung menurun dengan semakin lama waktu fermentasi. Penambahan gula dan waktu fermentasi menunjukkan bahwa perlakuan penambahan gula $25 \%$ dan fermentasi 21 hari memberikan $\mathrm{pH}$ terendah yaitu 2,82 , fermentasi berjalan pada suhu kamar. Lama waktu fermentasi bunga rosella sekitar 21 hari untuk dapat menghasilkan cuka rosella, Cuka rosella dihasilkan dari fermentasi melalui dua tahap yaitu tahap pertama dihasilkan alkohol selanjutnya tahap kedua dihasilkan asam asetat.

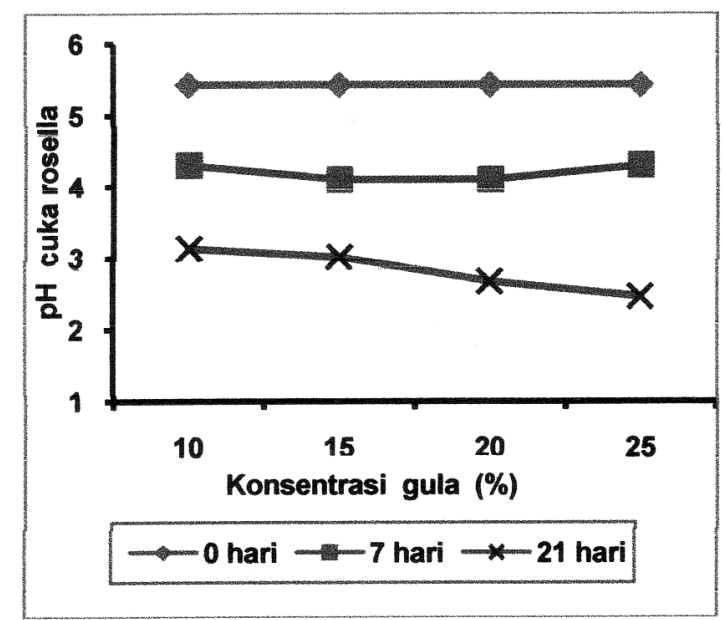

Gambar1. Pengaruh penambahan gula terhadap $\mathrm{pH}$ cuka rosella.

Meningkatnya kadar gula pasir ditambahkan menghasilkan $\mathrm{pH}$ cuka rosela semakin rendah hal ini disebabkan fermentasi tersebut akan menurunkan $\mathrm{pH}$ cuka rosella.(Gambar 2)

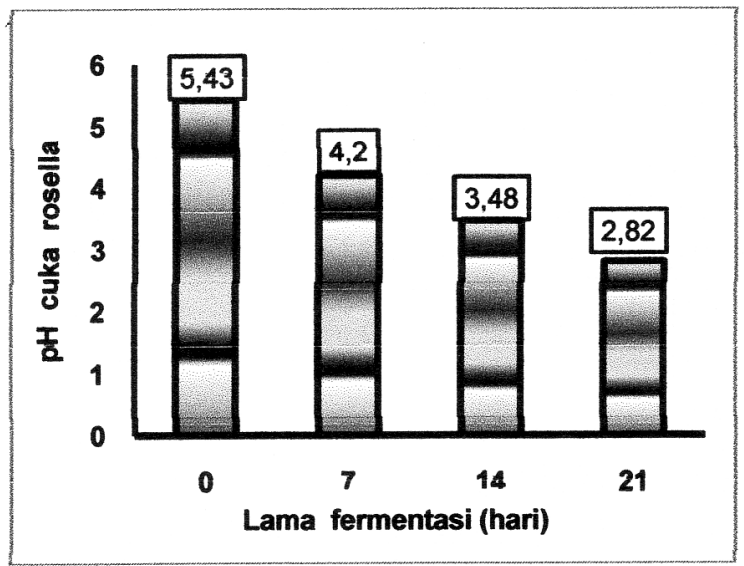

Gambar 2. Pengamatan waktu fermentasi terhadap $\mathrm{pH}$ pada pembuatan cuka rosella.

Pengaruh penambahan gula dan ragi terhadap kadar asam asetat cuka rosella.

Hasil uji asam asetat dari semua perlakuan berkisar $2,04-14,90 \%$, dimana terlihat perlakuan penambahan gula $25 \%$ dan ragi $6 \mathrm{~g} / \mathrm{L}$ menghasilkan asam asetat tertinggi $14,90 \%$ sedangkan asam asetat terendah pada perlakuan gula $10 \%$ dan ragi $2 \mathrm{~g} / \mathrm{L}$. 
Fermentasi rosella menjadi cuka terjadi dengan adanya senyawaan gula dengan penambahan ragi akan merombak senyawa gula menjadi monosakarida, dan dari monosakarida dengan bantuan ragi membentuk senyawa alkohol dan keluarnya gas $\mathrm{CO}_{2}$. Selanjutnya melalui bantuan bakteri acetobacter dan oksigen menghasilkan asam asetat dengan reaksi sebagai berikut :

$$
\begin{aligned}
& \mathrm{C}_{12} \mathrm{H}_{22} \mathrm{O}_{11}+\mathrm{H}_{2} \mathrm{O} \rightarrow \mathrm{C}_{6} \mathrm{H}_{12} \mathrm{O}_{6}+\mathrm{C}_{6} \mathrm{H}_{12} \mathrm{O}_{6} \\
& \text { (Sakarosa) (Glukosa) (Glukosa) } \\
& \mathrm{C}_{6} \mathrm{H}_{12} \mathrm{O}_{6} \rightarrow 2 \mathrm{C}_{2} \mathrm{H}_{5} \mathrm{OH}+2 \mathrm{CO}_{2}+2 \mathrm{ATP} \\
& \text { Gula alhohol Kdioksida + Energi } \\
& 2 \mathrm{C}_{2} \mathrm{H}_{5} \mathrm{OH} \rightarrow 2 \mathrm{CH}_{3} \mathrm{COOH}+\mathrm{H}_{2} \mathrm{O} \\
& \text { (Asam asetat) }
\end{aligned}
$$

Proses fermentasi akan merombak senyawa komplek menjadi lebih sederhana sehingga mudah dicerna dan diserap oleh tubuh dalam peningkatan gizi dan sifat sifat organoleptiknya. Fermentasi alami pada pembuatan cuka rosella dapat menyempurnakan kandungan nutrisi, vitamin dan mineral serta dapat mengaktifkan dan mengoptimalkan kwalitas kesehatan. Proses fermentasi asam asetat menurut Nurhidayat, dkk 2006 terjadi dalam dua tahap, pertama fermentasi alkohol dan tahap kedua adalah fermentasi asam asetat dengan bantuan bakteri asam asetat (Acetobacter $s p$ ) pada larutan yang mengandung alkohol (Zarlis dkk, 2011)

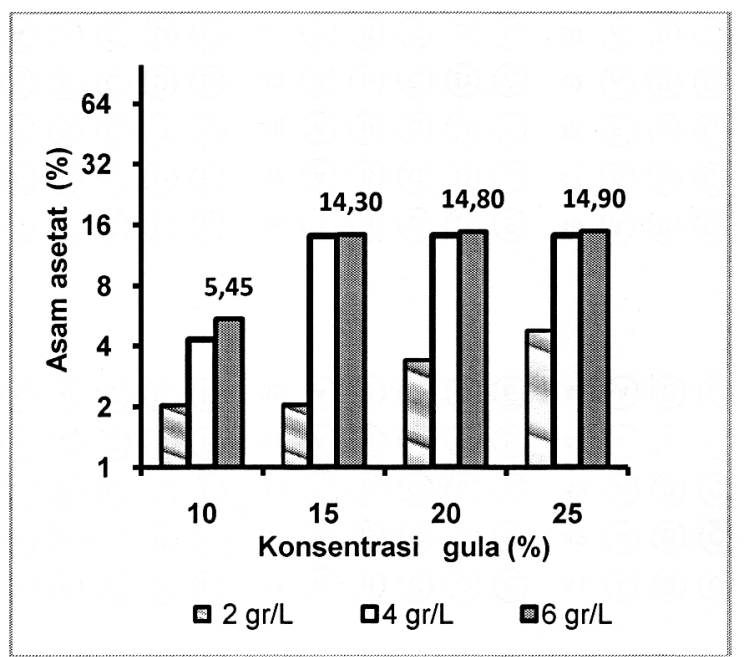

Gambar 3. Pengaruh penambahan gula dan ragi terhadap kadar asam asetat cuka rosella
Hasil kadar asam asetat yang dihasilkan pada penelitian dengan menggunakan rosella bila ditinjau dengan persyaratan SNI 01-3711-1995 yaitu persyaratan cuka makan 4-12,5\% memenuhi syarat mutu kecuali pada perlakuan gula $10 \%$ ragi 2 gr dan gula $15 \%$ ragi $2 \mathrm{gr}$.

\section{Pengaruh penambahan gula dan ragi terhadap kadar sari cuka rosella.}

Hasil penelitian terhadap kadar sari cuka rosella untuk semua perlakuan seperti terlihat pada Tabel 1. dimana kadar sari tertinggi pada perlakuan penambahan gula $10 \%$ dan ragi $6 \mathrm{~g} / \mathrm{L}(\mathrm{A} 1 \mathrm{~B} 3$ ) yaitu $8,05 \%$ dan terendah pada penambahan gula $20 \%$ dan ragi $2 \mathrm{~g} / \mathrm{L}$ yaitu $7,02 \%$.

Tabel 1. Hasil analisa rata-rata terhadap kadar sari dari cuka rosella.

\begin{tabular}{|r|c|c|}
\hline No & Perlakuan & $\begin{array}{c}\text { Rata-rata } \\
\text { kadar sari (\%) }\end{array}$ \\
\hline 1 & A1B1 & 7,45 \\
2 & A1B2 & 7,54 \\
3 & A1B3 & 8,05 \\
4 & A2B1 & 7,20 \\
5 & A2B2 & 7,22 \\
6 & A2B3 & 7,35 \\
7 & A3B1 & 7,02 \\
8 & A3B2 & 7,20 \\
9 & A3B3 & 7,15 \\
10 & A4B1 & 7,03 \\
11 & A4B2 & 7,12 \\
12 & A4B3 & 7,10 \\
\hline
\end{tabular}

Kadar sari merupakan banyaknya senyawa aktif yang terdapat di dalam suatu produk. Kadar sari dari cuka rosella berkurang selama fermentasi dan pembentukan asam asetat. Kadar sari merupakan sari rosella yang berada dalam cuka rosella yang secara fungsional bermanfaat sebagai serat dalam membantu pencernaan (Wirjatmadi, 2008). Dalam sari bunga rosella mengandung serat sebanyak $12 \%$, namun setelah terjadi fermentasi akan berkurang karena sebagian akan dirombak oleh Laktobacillus menjadi bahan yang lebih sederhana. 
Persen inhibisi, uji fenolik dan uji flavonoid.

Untuk melihat aktifitas antioksidan dari cuka rosella melalui uji fenolik, \% inhibisi dan uji flavonoid seperti pada Tabel 2.

Tabel 2. Hasil analisa rata-rata terhadap uji fenolik dan uji flavonoid, \% inhibisi dari cuka rosella

\begin{tabular}{|c|c|c|c|}
\hline $\begin{array}{c}\text { Perla- } \\
\text { kuan }\end{array}$ & $\begin{array}{c}\text { Uji } \\
\text { Fenolik }\end{array}$ & $\begin{array}{c}\text { Uji } \\
\text { Flavonoid }\end{array}$ & $\begin{array}{c}\% \\
\text { Inhibisi }\end{array}$ \\
\hline A1B1 & Positif & Positif & 53,3 \\
A1B2 & Positif & Positif & 58,7 \\
A1B3 & Positif & Positif & 55,2 \\
A2B1 & Positif & Positif & 55,4 \\
A2B2 & Positif & Positif & 54,3 \\
A2B3 & Positif & Positif & 50,5 \\
A3B1 & Positif & Positif & 43,7 \\
A3B2 & Positif & Positif & 50,1 \\
A3B3 & Positif & Positif & 48,5 \\
A4B1 & Positif & Positif & 52,1 \\
A4B2 & Positif & Positif & 34,2 \\
A4B3 & Positif & Positif & 31,0 \\
\hline
\end{tabular}

Hasil analisa menunjukkan semua perlakuan positif mengandung senyawaan fenolik dan flavanoid dan \% inhibisi 31,0 $59,7 \%$. Perlakuan pemberian gula pasir $10 \%$ dan ragi $4 \mathrm{~g} / \mathrm{L}$ menghasilkan $\%$ inhibisi tertinggi dari semua perlakuan. Adanya bahan aktif plavonoid dan fenolik dalam cuka rosella mempunyai manfaat fungsional yang cukup besar dalam mengobati berbagai penyakit seperti kanker terutama akan mengikat radikal bebas yang ada dalam tubuh.

Senyawa fenolik merupakan bahan antioksidan primer yang dapat menghentikan rantai radikal bebas oksidasi lemak. Menurut Sunarni,T (2005) antioksidan adalah senyawa yang dapat melindungi sel dari kerusakan yang disebabkan oleh ROS (Reactive Oxigen Species) dan kekuatannya bertambah dengan adanya berbagai vitamin lainnya yang ada dalam rosella tersebut.

Peranan zat antioksidan dalam cuka rosella ini merupakan penetralisir atau penyeimbang radikal bebas dalam mencegah berbagai penyakit kronis. Radikal bebas adalah molekul yang kehilangan elektron sehingga molekul itu menjadi tidak stabil dan selalu berusaha mengambil elektron dari molekul atau sel laindalam tubuh. Radikal bebas ini dihasilkan oleh metabolisme tubuh dan faktor faktor eksternal lainnya. Radikal bebas yang mengambil elektron dari sel tubuh dapat menyebabkan perubahan struktur DNA sehingga terbentuk sel mutan penyebab penyakit kronis. Di lain pihak tubuh sendiri menghasilkan zat antioksidan tetapi jumlahnya sedikit, untuk itu perlu pensuplai makanan fungsional yang mengandung zat antioksidan guna mengimbanginya. (Wirjatmadi, 2008).

\section{KESIMPULAN}

Berdasarkan hasil penelitian dapat disimpulkan bahwa bunga rosella dapat diolah menjadi cuka rosella didapatkan dengan penambahan gula dan bahan nutrisi diantaranya ragi dan dengan lama fermentasi sampai 3 minggu. Hasil penelitian optimal didapatkan pada perlakuan penambahan gula pasir $20 \%$ dan penambahan ragi $6 \mathrm{~g}$ dengan fermentasi selama tiga minggu. Cuka rosella positif mengandung senyawaan flavonoid dan senyawaan fenolik dan memiliki \% inhibisi $(31 \%-58,7 \%)$.

\section{DAFTAR PUSTAKA}

Allison L.Hopkins,Marnie G.Lamm, Janet L.Funk, Cheryl Ritenbaugh.2013. Hibiscus sabdariffa $\mathrm{L}$, in the treatment of hypertension and hyperlipidemia; A comprehensive review of animal and human studies. Journal Fitoterapia. Elsivier.

Apriyantono,A., dan C.H. Wijaya 2006 Metode Pengujian Organoleptik III. Dskriptif Test Modul Pelatihan Pengujian Bahan dan Produk Pangan. Fakultas Pertanian IPB Bogor.

Maria, Devi, 2009. Dahsyatnya Khasiat Rosella. Cemerlang Publishing, Yogyakarta.

Nurfaridah D, 2005. Manfaat Rosella. Departemen IImu dan Teknologi Pangan, Fakultas Teknologi Pertanian. IPB. Bogor. 
Nurhidayat, Masdiana,C.P dan Sri Suhartini. 2006. Mikrobiologi Industri. Penerbit Andi Yogyakarta.

Seema Patel. 2013. Hibiscus sabdariffa : An adeal yet under-exploited candidate for nutrraceuticall applications. Jurnal Biomedicine \& Preventive Nutrition XXX (20-13) Elsevier Masson France. ScienceDirect.

Sunarni,T., (2005). Aktivitas Antioksidan Penangkap Radikal Bebas Beberapa kecambah Dari Biji Tanaman Familia Papilionaceae, Jurnal Farmasi Indonesia

Wignyonto, Suarjono dan Novita, 2001. Pengaruh Konsentrasi Gula Reduksi Sari Nanas dan Inokulum Saccharomyces cerevisiae pada Fermentasi Etanol . Jurnal Teknologi Pertanian
Wirjatmadi Bambang.2008. Khasiat dan Manfaat Rosella Merah. Jawa Pos, Edisi Minggu, 7 Des 2008.

Zarlis, Firdausni, Triwahyu Ningsih dan Hasni, 2011. Pengaruh Jumlah Sari Bunga Rosella Dan Gula Terhadap Mutu Serta Ketahanan Selai Rosella.. Buletin BIPD. Baristand Industri Padang. Volume XIX No. 1 Tahun 2011. ISSN 0854-7319

Zoriah Aziz, Su Yuen Wong, Nyuk Jet Chong. 2013. Review of Effects of Hibiscus sabdariffa. L on serum lipids: A systematic review and meta-analysis. Journal of Ethnopharmacology. 